\title{
COMPARISON OF PVD COATINGS NACRO 4 AND TIALN + DLC DEPOSITED ON HIGH CONTACT RATIO GEARING INTERACTING WITH CONVENTIONAL AND ECOLOGICAL LUBRICANTS
}

\author{
Adam FÜRSTENZELLER ${ }^{1 *}$, František TÓTH ${ }^{1}$, Milan KADNÁR ${ }^{1}$, Juraj RUSNÁK${ }^{1}$, Miroslav BOŠANSKÝ \\ ${ }^{1}$ Slovak University of Agriculture in Nitra, Slovakia \\ ${ }^{2}$ Slovak University of Technology in Bratislava, Slovakia
}

\begin{abstract}
Proposed paper deals with experimental tests performed on the Nieman M01 FZG test rig. Experiments were carried out in accordance with STN 656280 standard for FZG scuffing tests, from which load values for each load level were obtained. HCR gears made of $16 \mathrm{MnCr} 5$ material were utilized during experimental tests. Gear surface was deposited by PVD coatings of $n A C R 0^{4}$ and TiAIN + DLC. Conventional lubricant MADIT PP 90H and biological lubricant OMW Biogear S150 were selected for lubrication environments. Aim of the experimental tests lied in application and comparison of PVD coatings deposited on HCR gears. Values of the maximum height of the assessed profile $R z$ for tip and reference diameters were measured after each load level. Results of experimental tests were statistically processed and relations between the maximum height of assessed profile $R z$ and load levels for both utilized coatings in both environments were established on the basis of these results.
\end{abstract}

Keywords: HCR gearing; PVD coating nACRo ${ }^{4}$; PVD coating TiAIN + DLC; FZG scuffing test; ecological oil introduction

Gears and power transmissions are the oldest mechanisms used in engineering. They were used whenever a man wanted to transfer mechanical energy to a working machine. Gears have undergone a long way of development to current state-of-the-art form of technology (Hoehn et al., 2008; Rackov et al., 2014; Kadnár et al., 2017).

High Contact Ratio (HCR) gears are non-standard gears with a modified form of a basic involute profile (Bošanský et al., 2013a). Changes are related to addendum height; it does not equal 1 like standard involute gears. Addendum height $h_{a}{ }^{*}$ increases and exceeds $1\left(h_{a}^{*}>1\right)$. Such gears have contact ratio $\varepsilon_{\alpha} \geq 2$. Teeth with this profile can reach contact ratio up to 4 (Tulík et al., 2017; Tulík et al., 2013; Máchal et al., 2013).

Principle of physical vapour deposition (PVD) lies in conversion of deposited material to the gas phase (evaporation, sputtering) in a vacuum, followed by application to a substrate at low temperatures $\left(150-500^{\circ} \mathrm{C}\right)$ (Lümkemann et al., 2014). Coating material or its components must be present directly in the deposition chamber, in which they are transferred to gaseous state. Typical layer thickness ranges from 1-5 $\mu \mathrm{m}$ (Hatamleh et al., 2009; Bošanský et al., 2013b; Dostál et al., 2019).

The PVD coating method was utilized for experimental study in order to ensure more appropriate temperature course during coating and lower procurement costs. Other method of coating with higher deposition temperatures was not utilized, since gears were surface-hardened and deposition temperature would exceed quench temperature
(Bobzin et al., 2009). After considering these factors and options in cooperation with the LISS CZ company, it was decided to use PVD coatings. Coating production was carried out in laboratories of LISS and selected coatings were deposited by means of the ARC PVD using device $\pi 411$ PLUS. Parameters of coatings used are described in the chapter Materials and Methods.

\section{Material and methods}

Experimental tests were performed at the Center of Innovation laboratories at the Faculty of Mechanical Engineering, Slovak University of Technology in Bratislava. Experiment was performed in accordance with STN 65 6280 standard for FZG (Forschungsstelle für Zahnräder und Getriebebau - Gear Research Centre) scuffing tests, from which the load values for different load levels were obtained (STN 656280, 1985). Experiment was performed using the FZG test rig (back-to-back) with closed performance flow, portable surface roughness tester Mitutoyo SJ-201 and ultrasonic cleaner Ecosom U7-STH (Bromark et al., 1992; Pengbo et al., 2017).

Niemann M01 device was developed at laboratories of the Slovak University of Technology in Bratislava for the comprehensive measurement of scuffing tests. Niemann M01 gear test rig is a back-to-back rig (Fig. 1).

The device itself is complemented by a number of devices for tracking of measured data during machine operation. 


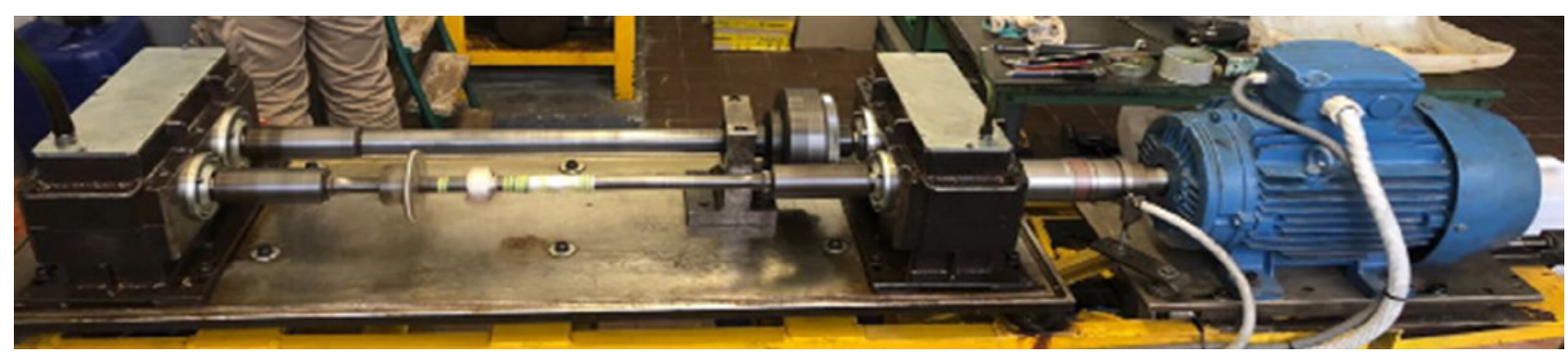

Fig. 1 Niemann M01 FZG back-to-back test rig

These devices serve as feedback to the data set before the measurement (Michalczewski et al., 2013).

Utilized lubricants for experimental tests included OMV BioGear S 150 and MADIT PP90H. The reason for using of biological and conventional lubricants was to test the durability and resistance of coating in selected lubricants under extreme conditions. Furthermore, specific types of lubricant - OMV Biogear S150 and MADIT PP 90H - were used since these were previously observed in experiments at the Center of Innovation, making it possible to compare them with previous research (Bošanský et al., 2012; Bošanský and Rusnák, 2017).

OMV Biogear S 150 is fully synthetic, biodegradable, industrial gear oil based on synthetic environment-friendly esters; basic specifications of this device are shown in Table 1. It is designed for mechanically and thermally heavy load transmissions of various constructions, for bearing lubrication in agriculture, forestry, construction industry, shipping and protcted natural areas.

Table 1 Technical properties of OMV Biohyd S 150 oil

\begin{tabular}{|l||c|}
\hline Property & Value \\
\hline Viscosity at $\mathbf{4 0}{ }^{\circ} \mathrm{C}$ & $150.00 \mathrm{~mm}^{2} \cdot \mathrm{s}^{-1}$ \\
\hline Viscosity at $100^{\circ} \mathrm{C}$ & $24.45 \mathrm{~mm}^{2} \cdot \mathrm{s}^{-1}$ \\
\hline Ignition point & $224^{\circ} \mathrm{C}$ \\
\hline Pour point & $-27^{\circ} \mathrm{C}$ \\
\hline Density at $15^{\circ} \mathrm{C}$ & $945 \mathrm{~kg} \cdot \mathrm{m}^{-3}$ \\
\hline Viscosity index & 167 \\
\hline
\end{tabular}

MADIT PP $90 \mathrm{H}$ is a year-round transmission oil designed to lubricate extremely heavy-duty transmissions and final-drive assemblies of modern cars and other mobile technology. Its basic specification is shown in Table 2.

Table 2 Technical data of MADIT PP 90H

\begin{tabular}{|l|c|}
\hline Property & Value \\
\hline Viscosity at $\mathbf{4 0}{ }^{\circ} \mathbf{C}$ & $140.00 \mathrm{~mm}^{2} \cdot \mathrm{s}^{-1}$ \\
\hline Viscosity at $\mathbf{1 0 0}{ }^{\circ} \mathbf{C}$ & $15.00 \mathrm{~mm}^{2} \cdot \mathrm{s}^{-1}$ \\
\hline Ignition point & $200^{\circ} \mathrm{C}$ \\
\hline Pour point & $-27^{\circ} \mathrm{C}$ \\
\hline Density at $\mathbf{1 5}{ }^{\circ} \mathbf{C}$ & $905 \mathrm{~kg} \cdot \mathrm{m}^{-3}$ \\
\hline Viscosity index & 95 \\
\hline
\end{tabular}

It is suitable for gearboxes working under extremely demanding operating conditions. It is designed for hypoid transmissions and is preferred in case of elevated temperatures, ensuring reliable function.

Portable surface roughness tester Mitutoyo SJ-201 with a retrofitted measuring apparatus was used for measuring of roughness before loading and after each load stage. The device was installed on the apparatus and used for measurement of the maximum height of assessed profile $R z$ on tip and reference diameter on both pinion and gear. Pinion and gear were degreased, washed in technical gasoline, cleaned from oil residues in an ultrasonic cleaner and dried with a flow of air before each measurement.

Test gears were made of $16 \mathrm{MnCr} 5$ steel and carburized, case hardened and tempered before coating. Basic parameters, such as the number of teeth of pinion and gear, are shown in Table 3.

\section{Table 3 Main parameters of test HCR gears}

\begin{tabular}{|l||c|}
\hline \multicolumn{1}{|l||}{ Property } & Value \\
\hline Transmission ratio & $i=2.43$ \\
\hline Centre distance & $a=144 \mathrm{~mm}$ \\
\hline Module $\quad$ gear & $m=4 \mathrm{~mm}$ \\
\hline Number of teeth - pinion & $z_{1}=21$ \\
\hline Face width $\quad z_{2}=51$ \\
\hline Reference cylinder helix angle & $b=15 \mathrm{~mm}$ \\
\hline Reference pressure angle & $\beta=0^{\circ}$ \\
\hline Addendum & $\alpha=20^{\circ}$ \\
\hline Dedendum & $h_{a}^{*}=1.3$ \\
\hline Profile shift correction - pinion & $h_{f}^{*}=1.7$ \\
\hline Tip diameter - pinion & $x_{1}=0.4$ \\
& $x_{2}=-0.4$ \\
\hline Traverse contact ratio & $d_{a_{1}}=97.6 \mathrm{~mm}$ \\
\hline
\end{tabular}

For the experimental tests, PVD coatings $\mathrm{nACRo}{ }^{4}$ and TiAIN + DLC were selected, the properties of which are shown in Table 4. Selected coatings are manufactured with a thickness ranging from 1 to $7 \mu \mathrm{m}$. The coating thickness of $7 \mu \mathrm{m}$ was utilized in experiment according to the standard.

Experimental tests for each coating were performed in 2 phases. In the first phase, experiments were carried out with OMV Biogear S150 ecological lubricant and with 
Table 4 Properties of $n A C R o^{4}$ and TiAIN + DLC coatings

\begin{tabular}{|l||c|c|}
\hline Property & nACRo & TiAIN + DLC \\
\hline Colour & Grey & Violet-black \\
\hline Nanohardness up to & $40 \mathrm{GPa}$ & $36 \mathrm{GPa}$ \\
\hline Thickness & $1-7 \mu \mathrm{m}$ & $1-7 \mu \mathrm{m}$ \\
\hline Friction coefficient & 0.45 & 0.60 \\
\hline Maximum usage temperature & $1,100^{\circ} \mathrm{C}$ & $700^{\circ} \mathrm{C}$ \\
\hline Deposition temperature & $480^{\circ} \mathrm{C}$ & $480^{\circ} \mathrm{C}$ \\
\hline
\end{tabular}

conventional lubricant MADIT PP $90 \mathrm{H}$ in the second phase. After completion of both phases, testing of another coating was carried out.

\section{Preparation of the test}

To avoid errors and inaccuracies, several steps had to be taken before each test in order to prepare the device and test gears:

- cleaning the chambers twice with a suitable solvent before starting a new series of experiments with a different lubricant;

- cleaning the pinion and gear in a solvent;

- weighing the pinion and gear on scale with an accuracy of at least $1 \mathrm{mg}$.

Conditions of experiment were determined by standard STN 65 6280:

- required circumferential velocity on the pinion $-v=$ $6.4 \mathrm{~m} \cdot \mathrm{s}^{-1}$, corresponding to the pinion revolutions of $1,450 \mathrm{rpm}$ in this case;

- test duration for each load stage $-20.6 \mathrm{~min}$, showing that the test pinion has performed 30,000 cycles (STN 656280, 1985).

Expected procedure for the experiment:

- insertion of testing gears into the test chamber, pouring of oil into chamber and assembling the measuring device;

- loading the test gears with the torque according to standard:
- launching the device for 20.6 min.;

- draining used oil;

- demounting the test chamber and removal of the test gear;

- degreasing the gears, washing the gears in technical gasoline and cleaning from oil residues in the ultrasonic cleaner, drying gears with the flow of dry air,

- weighing gears and measuring roughness.

\section{Results and discussion}

Experimental tests were performed on HCR gears, coated with $\mathrm{nACRo}{ }^{4}$ and TiAIN + DLC coatings in accordance with STN 656280 standard for FZG scuffing tests utilizing the Nieman M01 testing rig. Conventional lubricant MADIT PP $90 \mathrm{H}$ and ecological lubricant OMW Biogear S150 were selected for lubrication purposes. Results obtained from experimental tests were statistically processed and assessed. Test results were graphically evaluated as the course of the maximum height of the assessed profile $R z$ depending on the load level. Increasing load level was followed by a gradual increase of the $R z$ values caused by abrasion of the coating layers. When the value of the $R z$ would reach a limit $7 \mu \mathrm{m}$, this load level is marked as a border level of load.

Table 5 Values of the maximum height of the assessed profile $R z$ (pinion, $n A C R o^{4}$, Biogear S150)

\begin{tabular}{|l||c|c|c|c|c|c|c|c|}
\hline \multirow{2}{*}{ Load level } & \multicolumn{9}{|c|}{ Tip diameter } & \multicolumn{4}{c|}{ Reference diameter } \\
\cline { 2 - 10 } & $\mathbf{n}$ & $\boldsymbol{R}^{\prime} \mathbf{z}(\boldsymbol{\mu m})$ & $\boldsymbol{S}(\boldsymbol{\mu m})$ & $\mathbf{S}_{\boldsymbol{R}^{\prime} \mathbf{z}}(\boldsymbol{\mu m})$ & $\boldsymbol{n}$ & $\boldsymbol{R}^{\prime} \mathbf{z}(\boldsymbol{\mu m})$ & $\boldsymbol{S}_{(\boldsymbol{m})}$ & $\mathbf{S}_{\boldsymbol{R}^{\prime} \mathbf{z}}(\boldsymbol{\mu m})$ \\
\hline $\mathbf{3}$ & 10 & 5.600 & 0.189 & 0.059 & 10 & 3.65 & 0.092 & 0.029 \\
\hline $\mathbf{4}$ & 10 & 6.080 & 0.077 & 0.024 & 10 & 4.68 & 0.204 & 0.064 \\
\hline $\mathbf{5}$ & 10 & 5.670 & 0.061 & 0.019 & 10 & 3.11 & 0.086 & 0.027 \\
\hline $\mathbf{6}$ & 10 & 5.030 & 0.089 & 0.028 & 10 & 1.36 & 0.077 & 0.024 \\
\hline $\mathbf{7}$ & 10 & 3.760 & 0.165 & 0.052 & 10 & 1.20 & 0.074 & 0.023 \\
\hline $\mathbf{7 . 5}$ & 10 & 5.070 & 0.075 & 0.023 & 10 & 1.44 & 0.094 & 0.029 \\
\hline $\mathbf{8}$ & 10 & 5.460 & 0.085 & 0.027 & 10 & 1.85 & 0.079 & 0.025 \\
\hline $\mathbf{9}$ & 10 & 5.380 & 0.076 & 0.024 & 10 & 1.89 & 0.072 & 0.023 \\
\hline $\mathbf{1 0}$ & 10 & 2.770 & 0.092 & 0.029 & 10 & 1.24 & 0.044 & 0.014 \\
\hline $\mathbf{1 1}$ & 10 & 3.310 & 0.089 & 0.028 & 10 & 1.09 & 0.067 & 0.021 \\
\hline $\mathbf{1 2}$ & 10 & 2.700 & 0.154 & 0.049 & 10 & 1.40 & 0.076 & 0.024 \\
\hline
\end{tabular}


Table 6 Values of maximum height of the assessed profile $R z$ (gear, $\mathrm{nACRo}{ }^{4}$, Biogear S150)

\begin{tabular}{|l||c|c|c|c|c|c|c|c|}
\hline \multirow{2}{*}{ Load level } & \multicolumn{9}{|c|}{ Tip diameter } & \multicolumn{4}{c|}{ Reference diameter } \\
\cline { 2 - 10 } & $\boldsymbol{n}$ & $\boldsymbol{R}^{\prime} \mathbf{z}(\boldsymbol{\mu m})$ & $\boldsymbol{S}(\boldsymbol{\mu m})$ & $\mathbf{S}_{\boldsymbol{R}^{\prime} \mathbf{z}}(\boldsymbol{\mu m})$ & $\boldsymbol{n}$ & $\boldsymbol{R}^{\prime} \mathbf{z}(\boldsymbol{\mu m})$ & $\boldsymbol{S}_{(\boldsymbol{m})}$ & $\mathbf{S}_{\boldsymbol{R}^{\prime} \mathbf{z}}(\boldsymbol{\mu m})$ \\
\hline $\mathbf{3}$ & 10 & 5.890 & 0.094 & 0.030 & 10 & 3.61 & 0.110 & 0.035 \\
\hline $\mathbf{4}$ & 10 & 6.530 & 0.041 & 0.013 & 10 & 6.59 & 0.112 & 0.039 \\
\hline $\mathbf{5}$ & 10 & 5.880 & 0.056 & 0.018 & 10 & 4.48 & 0.107 & 0.034 \\
\hline $\mathbf{6}$ & 10 & 5.940 & 0.108 & 0.034 & 10 & 4.94 & 0.133 & 0.042 \\
\hline $\mathbf{7}$ & 10 & 5.410 & 0.069 & 0.022 & 10 & 4.14 & 0.117 & 0.037 \\
\hline $\mathbf{7 . 5}$ & 10 & 6.480 & 0.105 & 0.033 & 10 & 3.78 & 0.164 & 0.052 \\
\hline $\mathbf{8}$ & 10 & 6.360 & 0.098 & 0.031 & 10 & 4.68 & 0.154 & 0.049 \\
\hline $\mathbf{9}$ & 10 & 5.820 & 0.092 & 0.029 & 10 & 3.46 & 0.175 & 0.055 \\
\hline $\mathbf{1 0}$ & 10 & 5.640 & 0.104 & 0.033 & 10 & 4.07 & 0.133 & 0.042 \\
\hline $\mathbf{1 1}$ & 10 & 5.470 & 0.133 & 0.042 & 10 & 2.70 & 0.193 & 0.061 \\
\hline $\mathbf{1 2}$ & 10 & 5.150 & 0.112 & 0.035 & 10 & 2.70 & 0.198 & 0.063 \\
\hline
\end{tabular}

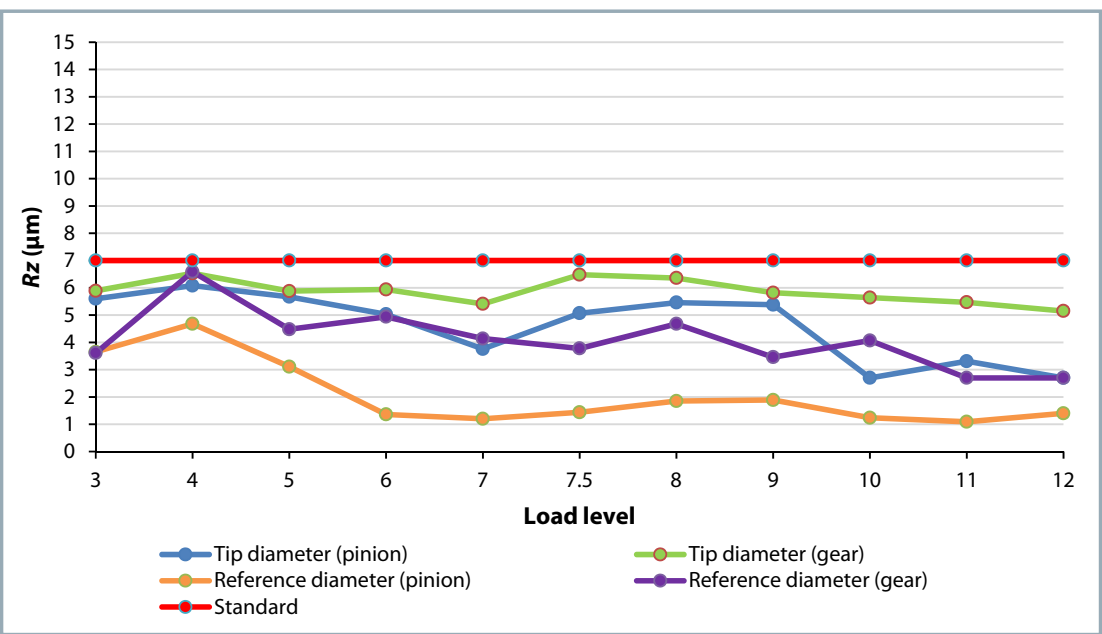

Fig. 2 Dependence of change maximum height of the assessed profile $R z$ on load level for $\mathrm{nACRo}^{4}$ in OMV Biogear S 150
Fig. 2 shows a change in the maximum height of the assessed profile $R z$ depending on the load level for both pinion and gear. Gear pair was coated by PVD coating $\mathrm{nACRo}{ }^{4}$ and lubricated with biological oil OMW Biogear S150. There are 5 lines in graph showing reference and tip diameters for the pinion and gear and limit value of the maximum height of the assessed profile $R z$ defined by the standard. These lines are colour-coded for better clarity. Tables 5 and 6 show that the maximum value of assessed profile $R z$ did not reach a limit value of $7 \mu \mathrm{m}$.

Fig. 3 shows a change in the maximum height of the assessed profile $R z$ depending on load level

Table 7 Values of the maximum height of the assessed profile $R z$ (pinion, $n A C R 0^{4}, M A D I T$ PP9OH)

\begin{tabular}{|c|c|c|c|c|c|c|c|c|}
\hline \multirow[t]{2}{*}{ Load level } & \multicolumn{4}{|c|}{ Tip diameter } & \multicolumn{4}{|c|}{ Reference diameter } \\
\hline & $n$ & $R^{\prime} z(\mu \mathrm{m})$ & $S(\mu \mathrm{m})$ & $S_{R^{\prime} z}(\mu \mathrm{m})$ & $n$ & $R^{\prime} z(\mu \mathrm{m})$ & $S(\mu \mathrm{m})$ & $S_{R^{\prime} z}(\mu \mathrm{m})$ \\
\hline 3 & 10 & 4.140 & 0.105 & 0.033 & 10 & 3.910 & 0.096 & 0.030 \\
\hline 4 & 10 & 5.310 & 0.156 & 0.049 & 10 & 4.010 & 0.163 & 0.052 \\
\hline 5 & 10 & 4.610 & 0.191 & 0.060 & 10 & 1.890 & 0.124 & 0.039 \\
\hline 6 & 10 & 4.010 & 0.144 & 0.045 & 10 & 2.520 & 0.132 & 0.042 \\
\hline 7 & 10 & 4.570 & 0.136 & 0.043 & 10 & 2.240 & 0.099 & 0.031 \\
\hline 7.5 & 10 & 3.550 & 0.137 & 0.043 & 10 & 4.180 & 0.130 & 0.983 \\
\hline 8 & 10 & 4.260 & 0.126 & 0.040 & 10 & 1.950 & 0.119 & 0.038 \\
\hline 9 & 10 & 4.640 & 0.155 & 0.049 & 10 & 1.340 & 0.150 & 0.048 \\
\hline 10 & 10 & 4.770 & 0.131 & 0.041 & 10 & 1.530 & 0.112 & 0.035 \\
\hline 11 & 10 & 5.180 & 0.128 & 0.040 & 10 & 1.660 & 0.123 & 0.038 \\
\hline 12 & 10 & 4.920 & 0.082 & 0.026 & 10 & 1.720 & 0.119 & 0.038 \\
\hline
\end{tabular}


Table 8 Values of the maximum height of the assessed profile $R z$ (gear, $n A C R 0^{4}, M A D I T$ PP9OH)

\begin{tabular}{|l||c|c|c|c|c|c|c|c|}
\hline \multirow{2}{*}{ Load level } & \multicolumn{9}{|c|}{ Tip diameter } & \multicolumn{4}{|c|}{ Reference diameter } \\
\cline { 2 - 10 } & $\boldsymbol{n}$ & $\boldsymbol{R}^{\prime} \mathbf{z}(\boldsymbol{\mu m})$ & $\boldsymbol{S}(\boldsymbol{\mu m})$ & $\mathbf{S}_{\boldsymbol{R}^{\prime} \mathbf{z}}(\boldsymbol{\mu m})$ & $\boldsymbol{n}$ & $\boldsymbol{R}^{\prime} \mathbf{z}(\boldsymbol{\mu m})$ & $\boldsymbol{S}_{(\boldsymbol{m})}$ & $\mathbf{S}_{\boldsymbol{R}^{\prime} \mathbf{z}}(\boldsymbol{\mu m})$ \\
\hline $\mathbf{3}$ & 10 & 6.040 & 0.131 & 0.041 & 10 & 5.030 & 0.114 & 0.036 \\
\hline $\mathbf{4}$ & 10 & 5.510 & 0.159 & 0.050 & 10 & 5.010 & 0.144 & 0.046 \\
\hline $\mathbf{5}$ & 10 & 5.510 & 0.147 & 0.047 & 10 & 4.260 & 0.103 & 0.033 \\
\hline $\mathbf{6}$ & 10 & 6.670 & 0.131 & 0.042 & 10 & 4.240 & 0.138 & 0.044 \\
\hline $\mathbf{7}$ & 10 & 4.890 & 0.121 & 0.038 & 10 & 5.560 & 0.120 & 0.038 \\
\hline $\mathbf{7 . 5}$ & 10 & 5.530 & 0.104 & 0.033 & 10 & 4.520 & 0.114 & 0.036 \\
\hline $\mathbf{8}$ & 10 & 5.810 & 0.129 & 0.041 & 10 & 2.210 & 0.115 & 0.036 \\
\hline $\mathbf{9}$ & 10 & 4.990 & 0.126 & 0.040 & 10 & 3.880 & 0.121 & 0.038 \\
\hline $\mathbf{1 0}$ & 10 & 5.840 & 0.174 & 0.055 & 10 & 1.510 & 0.141 & 0.044 \\
\hline $\mathbf{1 1}$ & 10 & 4.810 & 0.102 & 0.032 & 10 & 2.850 & 0.122 & 0.039 \\
\hline $\mathbf{1 2}$ & 10 & 5.370 & 0.148 & 0.047 & 10 & 3.090 & 0.110 & 0.035 \\
\hline
\end{tabular}

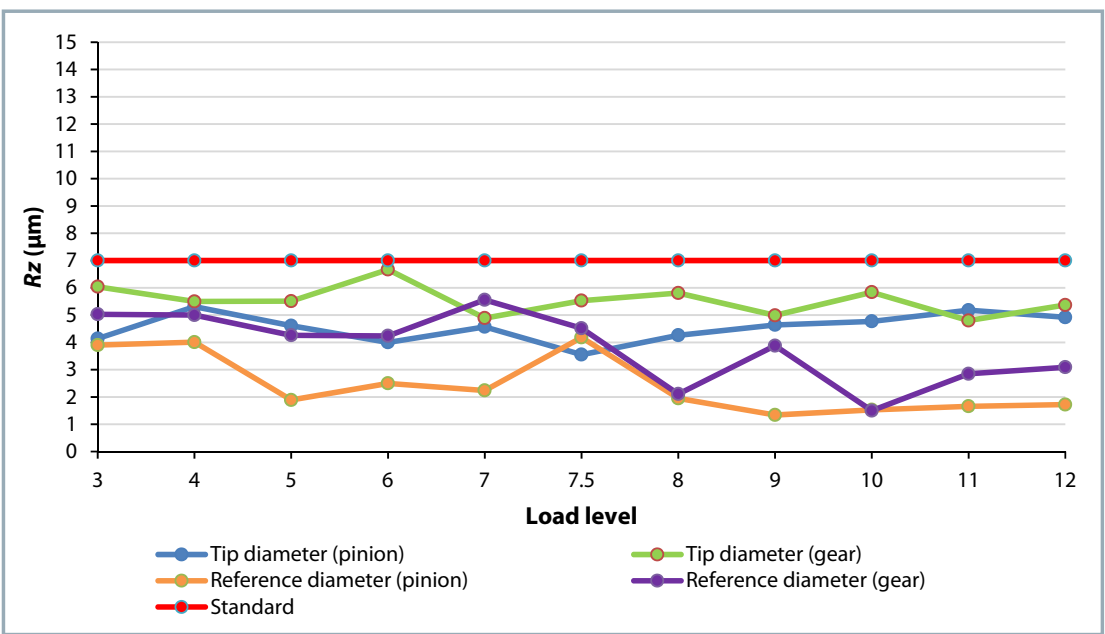

Fig. 3 Dependence of change in the maximum height of the assessed profile $R z$ on load level for $n A C R o^{4}$ in MADIT PP $90 \mathrm{H}$ for both pinion and gear. Gear pair was coated by PVD coating $\mathrm{nACRo}^{4}$ and lubricated with conventional oil MADIT PP $90 \mathrm{H}$. There are 5 lines in the graph showing the reference and tip diameters for the pinion and gear and limit value of the maximum height of the assessed profile $R z$ defined by the standard. These lines are colourcoded for better clarity. Tables 7 and 8 show that the maximum value of the assessed profile $R z$ did not reach a limit value of $7 \mu \mathrm{m}$.

Fig. 4 shows a change in the maximum height of the assessed profile $R z$ depending on load level for both pinion and gear. Gear pair was coated by PVD coating TiAIN + DLC and

Table 9 Values of the maximum height of the assessed profile $R z$ (pinion, TiAIN + DLC, Biogear S150)

\begin{tabular}{|c|c|c|c|c|c|c|c|c|}
\hline \multirow[t]{2}{*}{ Load level } & \multicolumn{4}{|c|}{ Tip diameter } & \multicolumn{4}{|c|}{ Reference diameter } \\
\hline & $n$ & $R^{\prime} z(\mu \mathrm{m})$ & $S(\mu \mathrm{m})$ & $S_{R^{\prime} z}(\mu \mathrm{m})$ & $n$ & $R^{\prime} z(\mu \mathrm{m})$ & $S(\mu \mathrm{m})$ & $S_{R^{\prime} z}(\mu \mathrm{m})$ \\
\hline 3 & 10 & 6.920 & 0.137 & 0.043 & 10 & 6.410 & 0.113 & 0.036 \\
\hline 4 & 10 & 5.760 & 0.127 & 0.040 & 10 & 4.710 & 0.098 & 0.031 \\
\hline 5 & 10 & 6.210 & 0.134 & 0.042 & 10 & 5.070 & 0.144 & 0.036 \\
\hline 6 & 10 & 4.910 & 0.176 & 0.056 & 10 & 5.350 & 0.130 & 0.033 \\
\hline 7 & 10 & 5.030 & 0.160 & 0.034 & 10 & 4.360 & 0.121 & 0.038 \\
\hline 7.5 & 10 & 4.830 & 0.139 & 0.044 & 10 & 5.890 & 0.114 & 0.036 \\
\hline 8 & 10 & 6.340 & 0.128 & 0.041 & 10 & 3.970 & 0.134 & 0.042 \\
\hline 9 & 10 & 4.840 & 0.117 & 0.037 & 10 & 2.710 & 0.123 & 0.039 \\
\hline 10 & 10 & 5.790 & 0.145 & 0.046 & 10 & 2.870 & 0.136 & 0.043 \\
\hline 11 & 10 & 5.780 & 0.145 & 0.046 & 10 & 3.940 & 0.104 & 0.033 \\
\hline 12 & 10 & 5.080 & 0.128 & 0.040 & 10 & 2.240 & 0.096 & 0.030 \\
\hline
\end{tabular}


Table 10 Values of the maximum height of the assessed profile $R z$ (gear, TiAIN+DLC, Biogear S150)

\begin{tabular}{|l||c|c|c|c|c|c|c|c|}
\hline \multirow{2}{*}{ Load level } & \multicolumn{9}{|c|}{ Tip diameter } & \multicolumn{4}{c|}{ Reference diameter } \\
\cline { 2 - 10 } & $\boldsymbol{n}$ & $\boldsymbol{R}^{\prime} \mathbf{z}(\boldsymbol{\mu m})$ & $\boldsymbol{S}(\boldsymbol{\mu m})$ & $\mathbf{S}_{\boldsymbol{R}^{\prime} \mathbf{z}}(\boldsymbol{\mu m})$ & $\boldsymbol{n}$ & $\boldsymbol{R}^{\prime} \mathbf{z}(\boldsymbol{\mu m})$ & $\boldsymbol{S}_{(\boldsymbol{m})}$ & $\mathbf{S}_{\boldsymbol{R}^{\prime} \mathbf{z}}(\boldsymbol{\mu m})$ \\
\hline $\mathbf{3}$ & 10 & 5.510 & 0.089 & 0.028 & 10 & 6.730 & 0.094 & 0.030 \\
\hline $\mathbf{4}$ & 10 & 6.250 & 0.139 & 0.044 & 10 & 5.750 & 0.086 & 0.027 \\
\hline $\mathbf{5}$ & 10 & 5.740 & 0.116 & 0.037 & 10 & 4.890 & 0.084 & 0.026 \\
\hline $\mathbf{6}$ & 10 & 5.410 & 0.106 & 0.033 & 10 & 4.870 & 0.085 & 0.027 \\
\hline $\mathbf{7}$ & 10 & 5.210 & 0.088 & 0.028 & 10 & 4.870 & 0.067 & 0.021 \\
\hline $\mathbf{7 . 5}$ & 10 & 5.440 & 0.102 & 0.032 & 10 & 4.230 & 0.076 & 0.024 \\
\hline $\mathbf{8}$ & 10 & 6.060 & 0.122 & 0.039 & 10 & 4.340 & 0.095 & 0.030 \\
\hline $\mathbf{9}$ & 10 & 5.970 & 0.096 & 0.030 & 10 & 5.320 & 0.0118 & 0.037 \\
\hline $\mathbf{1 0}$ & 10 & 4.460 & 0.106 & 0.034 & 10 & 5.240 & 0.070 & 0.022 \\
\hline $\mathbf{1 1}$ & 10 & 5.510 & 0.099 & 0.031 & 10 & 4.790 & 0.090 & 0.028 \\
\hline $\mathbf{1 2}$ & 10 & 5.450 & 0.098 & 0.032 & 10 & 4.140 & 0.079 & 0.025 \\
\hline
\end{tabular}

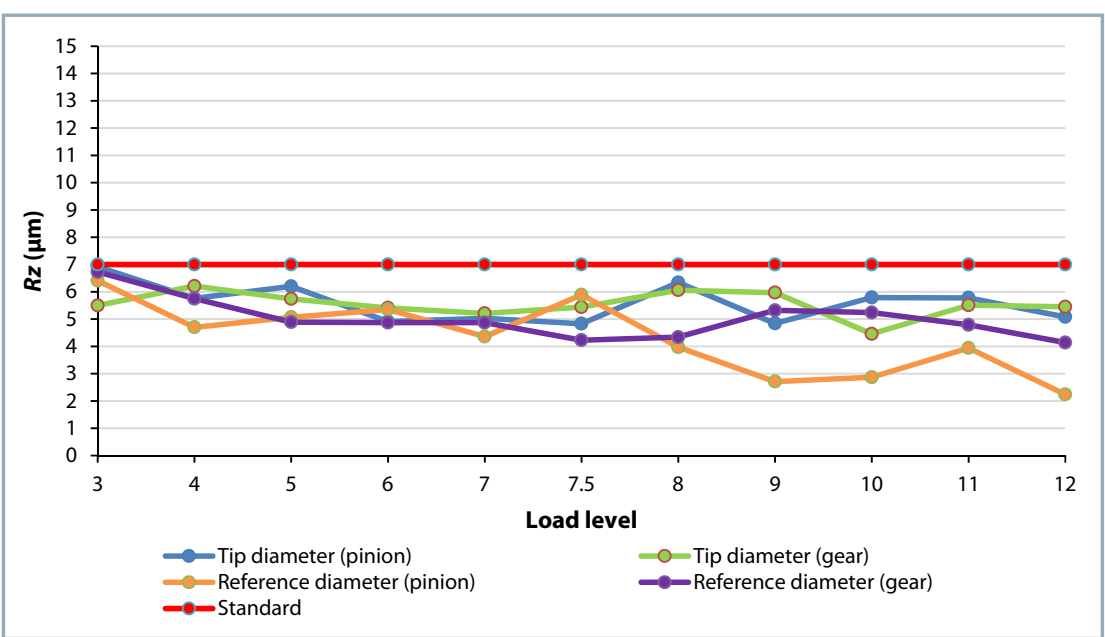

Fig. 4 Dependence of change in the maximum height of the assessed profile $R z$ on load level for TiAIN+DLC in OMW Biogear S150 lubricated with conventional oil OMW Biogear S150. There are 5 lines in the graph showing the reference and tip diameters for the pinion and the gear and limit value of the maximum height of the assessed profile $R z$ defined by the standard. These lines are colourcoded for better clarity. Tables 9 and 10 show that the maximum value of the assessed profile $R z$ did not reach a limit value of $7 \mu \mathrm{m}$.

Fig. 5 shows a change in the maximum height of the assessed profile $R z$ depending on load level for both the pinion and the gear. Gear pair was coated by PVD coating TiAIN + DLC and lubricated with conventional oil MADIT PP $90 \mathrm{H}$. There are 5 lines in the

Table 11 Values of the maximum height of the assessed profile $R z$ (pinion, TiAIN + DLC, MADIT PP 90H)

\begin{tabular}{|c|c|c|c|c|c|c|c|c|}
\hline \multirow[t]{2}{*}{ Load level } & \multicolumn{4}{|c|}{ Tip diameter } & \multicolumn{4}{|c|}{ Reference diameter } \\
\hline & $n$ & $R^{\prime} z(\mu \mathrm{m})$ & $S(\mu \mathrm{m})$ & $S_{R^{\prime} z}(\mu \mathrm{m})$ & $n$ & $R^{\prime} z(\mu \mathrm{m})$ & $S(\mu \mathrm{m})$ & $S_{R^{\prime} z}(\mu \mathrm{m})$ \\
\hline 3 & 10 & 4.770 & 0.072 & 0.023 & 10 & 3.680 & 0.081 & 0.026 \\
\hline 4 & 10 & 5.260 & 0.061 & 0.019 & 10 & 3.270 & 0.058 & 0.018 \\
\hline 5 & 10 & 4.830 & 0.071 & 0.023 & 10 & 3.410 & 0.082 & 0.026 \\
\hline 6 & 10 & 5.770 & 0.073 & 0.023 & 10 & 3.420 & 0.063 & 0.020 \\
\hline 7 & 10 & 5.570 & 0.069 & 0.022 & 10 & 3.590 & 0.062 & 0.019 \\
\hline 7.5 & 10 & 5.480 & 0.077 & 0.024 & 10 & 2.960 & 0.085 & 0.027 \\
\hline 8 & 10 & 3.540 & 0.059 & 0.019 & 10 & 2.550 & 0.098 & 0.031 \\
\hline 9 & 10 & 5.010 & 0.063 & 0.020 & 10 & 3.110 & 0.083 & 0.026 \\
\hline 10 & 10 & 5.260 & 0.090 & 0.029 & 10 & 3.630 & 0.087 & 0.028 \\
\hline 11 & 10 & 4.990 & 0.069 & 0.022 & 10 & 3.890 & 0.110 & 0.035 \\
\hline 12 & 10 & 4.310 & 0.064 & 0.020 & 10 & 4.470 & 0.085 & 0.027 \\
\hline
\end{tabular}


Table 12 Values of the maximum height of the assessed profile $R z$ (gear, TiAIN+DLC, MADIT PP 90H)

\begin{tabular}{|l||c|c|c|c|c|c|c|c|}
\hline \multirow{2}{*}{ Load level } & \multicolumn{9}{|c|}{ Tip diameter } & \multicolumn{4}{c|}{ Reference diameter } \\
\cline { 2 - 10 } & $\boldsymbol{n}$ & $\boldsymbol{R}^{\prime} \mathbf{z}(\boldsymbol{\mu m})$ & $\boldsymbol{S}(\boldsymbol{\mu m})$ & $\mathbf{S}_{\boldsymbol{R}^{\prime} \mathbf{z}}(\boldsymbol{\mu m})$ & $\boldsymbol{n}$ & $\boldsymbol{R}^{\prime} \mathbf{z}(\boldsymbol{\mu m})$ & $\boldsymbol{S}_{(\boldsymbol{m})}$ & $\mathbf{S}_{\boldsymbol{R}^{\prime} \mathbf{z}}(\boldsymbol{\mu m})$ \\
\hline $\mathbf{3}$ & 10 & 5.530 & 0.086 & 0.027 & 10 & 5.680 & 0.078 & 0.025 \\
\hline $\mathbf{4}$ & 10 & 6.560 & 0.089 & 0.028 & 10 & 5.210 & 0.074 & 0.023 \\
\hline $\mathbf{5}$ & 10 & 4.750 & 0.105 & 0.033 & 10 & 5.910 & 0.091 & 0.029 \\
\hline $\mathbf{6}$ & 10 & 3.810 & 0.090 & 0.028 & 10 & 4.360 & 0.086 & 0.027 \\
\hline $\mathbf{7}$ & 10 & 5.870 & 0.074 & 0.024 & 10 & 6.050 & 0.096 & 0.030 \\
\hline $\mathbf{7 . 5}$ & 10 & 6.440 & 0.104 & 0.033 & 10 & 3.410 & 0.077 & 0.024 \\
\hline $\mathbf{8}$ & 10 & 4.780 & 0.107 & 0.034 & 10 & 5.470 & 0.091 & 0.029 \\
\hline $\mathbf{9}$ & 10 & 5.720 & 0.0106 & 0.033 & 10 & 4.580 & 0.088 & 0.028 \\
\hline $\mathbf{1 0}$ & 10 & 6.610 & 0.117 & 0.037 & 10 & 2.930 & 0.087 & 0.027 \\
\hline $\mathbf{1 1}$ & 10 & 4.480 & 0.085 & 0.027 & 10 & 3.290 & 0.112 & 0.036 \\
\hline $\mathbf{1 2}$ & 10 & 5.640 & 0.117 & 0.037 & 10 & 2.990 & 0.104 & 0.033 \\
\hline
\end{tabular}

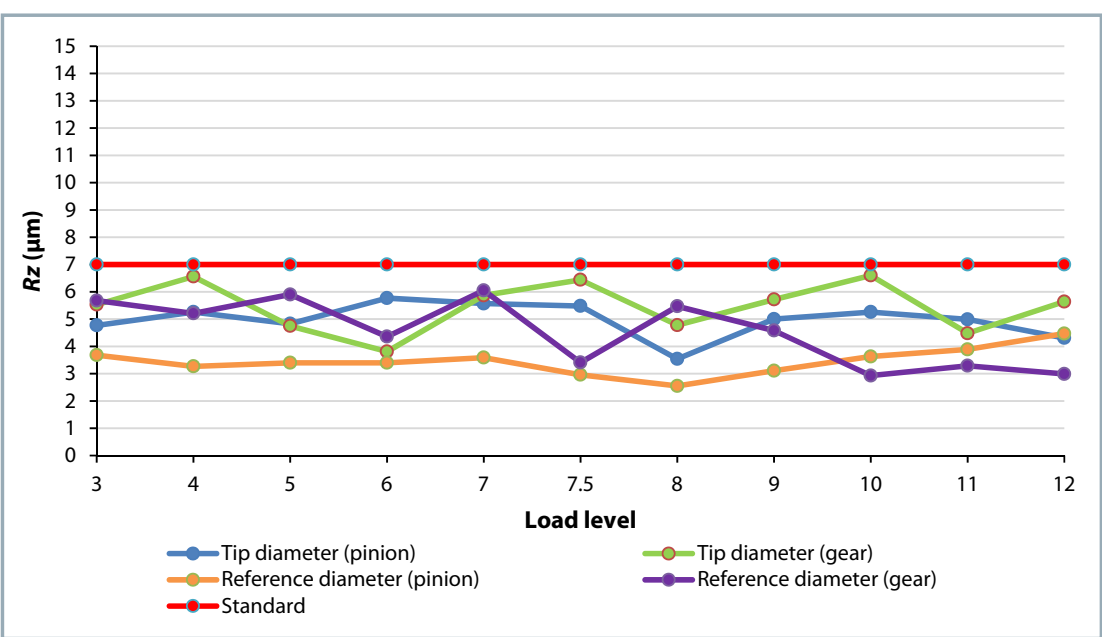

Fig. 5 Dependence of change in the maximum height of the assessed profile $R z$ on load level for TiAIN+DLC in MADIT PP 90H

graph showing the reference and tip diameters for the pinion and the gear and limit value of the maximum height of the assessed profile $R z$ defined by the standard. These lines are colourcoded for better clarity. Tables 11 and 12 show that the maximum value of the assessed profile $R z$ did not reach a limit value of $7 \mu \mathrm{m}$.

In comparison to research previously carried out at the Centre of Innovations of the Slovak University of Technology in Bratislava, it is possible to conclude that the adhesive properties and wear resistance of the coatings nACRo ${ }^{4}$ and TiALN + DLC have shown better results than previously observed TiCN-MP coating + MOVIC (Mišány, 2015), since in observing those, scuffing occurred at the $11^{\text {th }}$ load level, as well as and DLC coating (Zápotočný, 2014) where scuffing occurred at the $7^{\text {th }}$ load level.

\section{Conclusion}

Experimental test was carried out on HCR gears coated by PVD coatings $\mathrm{nACRo}{ }^{4}$ and TiAIN+DLC. Conventional oil MADIT PP9OH and biological oil OMW Biogear S150 were selected for lubrication environments. Both coatings were deposited in ACR PVD mode with the $\pi 411$ PLUS device. Coatings were produced at a thickness of $7 \mu \mathrm{m}$ and tested according to STN 656280 standard. Measured values were evaluated statistically in the form of tables and graphically as the dependency of the maximum height of the assessed profile $R z$ in relation to the load level. In terms of obtained values, it is evident that the maximum height of the assessed profile $R z$ did not exceed interval $7 \mu \mathrm{m}$ established by the standard. Therefore, it can be concluded that scuffing did not occur, and adhesive properties and wear resistance of selected coatings are satisfactory for both lubricating mediums.

\section{Acknowledgements}

The contribution has been prepared within the scientific grant project VEGA 1/0227/15 "Study of tribological characteristics of the new high hard coatings on materials suitable for gearings".

\section{References}

BOBZIN, K. - BAGCIVAN, N. - GOEBBELS, N. - YILMAZ, K. - HOEHN, B. R. - MICHAELIS, K. - HOCHMANN, M. 2009. Lubricated PVD coatings for automotive applications. In Surface and Coatings Technology, vol. 204, pp. 1097-1101.

BOŠANSKÝ, M. - VEREŠ, M. - TÖKÖLY, P. - VANYA, A. 2012. Non-standard Gears. Bratislava : SUT in Bratislava, 159 pp. ISBN 9788022737135. (In Slovak: Neštandardné ozubené prevody).

BOŠANSKÝ, M. - VANYA, A. - ČAPLOVIČ, L. - HUDÁKOVÁ, M. - SONDOR, J. 2013a. Evaluation of properties of selected coatings on Aisi Grade $18 \mathrm{Ni}(250)$ maraging steel in terms of their use in gears. In Advanced Materials Research, vol. 746, pp. 179-185. 
BOŠANSKÝ, M. - VANYA, A. - VEREŠ, M. 2013b. Evaluation of properties of selected coatings on steel C60E in terms of their use in gearing. In Advanced Materials Research, no. 25, pp. 81-85.

BOŠANSKÝ, M. - RUSNÁK, J. 2017. Assessment of options for applications TICN-MP + movic deposited on the convex-concave gearing working in interaction with the ecological lubricant. In Proceedings of $58^{\text {th }}$ International Conference of Machine Design Departments. ICMD 2017. Prague : Czech University of Life Sciences Prague, pp. 44-49.

BROMARK, M. - LARSSON, M. - HEDENQVIST, P. - OLSSON, M. - HOGMARK, S. 1992. Influence of substrate and surface topography on the critical surface force in scratch adhesion testing of TiN-coated steels. In Surface Coating Technology, vol. 52 pp. $195-203$.

DOSTÁL, P. - ROZLIVKA, J. - KUMBÁR, V. 2019. Operational degradation of engine oil in agricultural technology. In Acta Technologica Agriculturae, vol. 22, no. 1, pp. 17-21.

HATAMLEH, O. - SMITH, J. - COHEN, D. - BRADLEY, R. 2009. Surface roughness and friction coefficient in peened friction stir welded 2195 aluminum alloy. In Applied Surface Science, vol. 255, no. 16, pp. $7414-7426$

HOEHN, B. R. - OSTER, P. - TOBIE, T. - MICHAELIS, K. 2008. Test methods for gear lubricants. In Goriva i Maziva, vol. 47, no. 2, pp. 129-157.

KADNÁR, M. - RUSNÁK, J. - TKÁČ, Z. - BOŠANSKÝ, M. 2017. Tribological experiments in automobile industry. In Visnik Nacional'novo Techničnovo Universitetu " CHPI", no. 25, pp. 81-85.

LÜMKEMANN, A. - BEUTNER, M. - MORSTEIN, M. - KÖCHIG, M. WENGLER, M. - CSELLE, T. - KARPUSCHEWSKI, B. 2014. A New Generation of PVD Coatings for High-Performance Gear Hobbing. In Coatings Conference. Thessaloniki, Greece, Oct.1-3, 2014.

MÁCHAL, P. - TKÁČ, Z. - KOSIBA, J. - JABLONICKÝ, J. - HUJO, L. KUČERA, M. - TULÍK, J. 2013. Design of a laboratory hydraulic device for testing of hydraulic pumps. In Acta Universitatis Agriculturae et Silviculturae Mendelianae Brunensis, vol. 61, no. 5, pp. 1313-1319.
MICHALCZEWSKI, R. - KALBARCZYK, M. - MICHALAK, M. PIEKOSZEWSKI, W. - SZCZEREK, M. - TUSZYNSKI, W. - WILCZYNSKI, J. 2013. New scuffing test methods for the determination of the scufing resistance of coated gears. In Tribology - Fundamentals and Advancements, vol. 12, no. 4, pp.187-215.

MIŠÁNY, J. 2015. Influence of the building machine transmission and the possibility to increase its carrying capacity with a focus to reduce the environmental load of soil. Bratislava : SUT in Bratislava, 115 pp. (In Slovak: Vplyv prevodového ústrojenstva stavebného stroja a možnosti zvýšenia jeho únosnosti so zameraním na zniženie ekologického zat̉aženia pôdy).

PENGBO, M. I. - JINING, H. E. - YANFANG, Q. - KAI, C. 2017. Nanostructure reactive plasma sprayed TiCN coating. In Surface and Coatings Technology, vol. 309, pp. 1-5

RACKOV, M. - MILOVANČEVIĆ, M. - KANOVIĆ, Ž. - VEREŠ, M. RAFA, K. - BANIĆ, M. - MILTENOVIĆ, A. 2014. Optimalization of HCR gearing geometry using generalized particle swarm optimalization algorithm. In Modern Methods of Construction Design, vol. 109, no. 10 , pp. 539-545.

STN 656280: 1985 Lubricants. Mechanical testing of lubricants in the FZG gear ring test machine.

TULÍK, J. - HUJO, L. - KOSIBA, J. - JABLONICKÝ J. - JÁNOŠOVÁ, M. 2017. Evaluation of new biodegradable fluid on the basis of accelerated durability test, FTIR and ICP spectroscopy. In Research in Agricultural Engineering, vol. 63, no. 1, pp. 1-9.

TULÍK, J. - KOSIBA, J. - BUREŠ, L. - ŠINSKÝ V. 2013. Analysis of synthetic oil samples during an operating test. In Acta Technologica Agriculturae, vol. 16, no. 1, pp. 21-24

ZÁPOTOČNÝ, J. 2014. Analysis of qualitative and quantitative characteristics of placed films in the system 'film - cog side' from the tribological point of view. Bratislava : SUT in Bratislava. (In Slovak: Určenie kvalitatívnych a kvantitatívnych charakteristík deponovaných povlakov $v$ systéme povlak bok zuba z tribologického hladiska). 